\title{
EDUKASI PENCEGAHAN CORONA VIRUS DISEASE 2019 (COVID 19) PADA IBU HAMIL DI KOTA BENGKULU
}

\section{EDUCATION TO PREVENTIVE PRENANCY WOMEN IN CORONA VIRUS DISEASE 2019 PANDEMI AT BENGKULU CITY}

\author{
Kurnia Dewiani $^{1 *}$, Yetti Purnama ${ }^{2)}$, Linda Yusanti ${ }^{3)}$ \\ ${ }^{1)}$ Fakultas Matematika dan Ilmu Pengetahuan Alam Universitas Bengkulu \\ email: kdewiani@unib.ac.id \\ ${ }^{2)}$ Fakultas Matematika dan Ilmu Pengetahuan Alam Universitas Bengkulu \\ email: ypurnama@unib.ac.id \\ ${ }^{3)}$ Fakultas Matematika dan Ilmu Pengetahuan Alam Universitas Bengkulu \\ email: lyusanti@unib.ac.id
}

\begin{abstract}
ABSTRAK
Kota Bengkulu tertanggal 13 Oktober 2020 merupakan Kabupaten/Kota di provinsi Bengkulu yang memiliki angka positif Covid 19 terbesar yaitu 485 dengan angka kematian 30. Ibu hamil merupakan salah satu kelompok rentan terpapar virus covid 19, ibu hamil memiliki risiko lebih tinggi terjangkit penyakit berat, morbiditas dan mortalitas dibandingkan dengan populasi umum. Tujuan pengabdian adalah mencegah ibu hamil di Kota Bengkulu tertular Covid 19 dengan meningkatkan pemahaman tentang Covid 19 dan keterampilan cuci tangan serta pengunaan masker yang benar. Kegiatan dilaksanakan dengan metode door to door dengan ibu hamil dan mematuhi protokol kesehatan. Sasaran ibu hamil sebanyak 50 orang. Kegiatan dilakukan mulai dari pengukuran pemahaman tentang Covid 19 dengan kuisioner dan daftar tilik keterampilan cuci tangan dan penggunaan masker yang benar, selanjutnya tim melakukan pendampingan dan edukasi dengan menggunakan bantuan leaflet dan mendemonstrasikan keterampilan. Selain itu ibu hamil juga diberikan 1 set paket yang berisi vitamin, masker medis, sabun cuci tangan dan hand sanitizer. Evaluasi kegiatan dilakukan 2 minggu setelah implementasi. Hasil didapatkan ibu hamil mengalami peningkatan pengetahuan lebih dari $80 \%$ dan menerapkan pola hidup sehat lebih dari $75 \%$, serta merasa lebih tenang karena telah didampingi dan diedukasi oleh tim pengabdi. Kesimpulan ibu hamil mengalami peningkatan pengetahuan tentang Covid 19 dan keterampilan cuci tangan dan penggunaan masker yang benar, sehingga dapat mencegah ibu hamil tertular Covid 19.
\end{abstract}

Kata kunci: Ibu Hamil, Protokol Pencegahan Covid 19

\section{ABSTRACT}

Bengkulu City, dated October 13, 2020, is a regency / city in Bengkulu province that has the largest positive number of Covid 19, namely 485 with a mortality rate of 30.Pregnant women are one of the groups vulnerable to exposure to the Covid 19 virus, pregnant women have a higher risk of contracting serious diseases and mortality compared to the general population.The aim of this service is to prevent pregnant women in Bengkulu City from contracting Covid 19 by increasing their understanding of Covid 19 and the skills in washing hands and using the correct mask. Activities carried out by the door to door method with pregnant women and complying with health protocols. The target of pregnant women is 50 people. Activities carried out starting from measuring understanding of Covid 19 with questionnaires and checklists of hand washing skills and the correct use of masks, then the team carried out mentoring and education using leaflets and demonstrating skills In addition, pregnant women are also given a set of packages containing vitamins, medical masks, hand washing soap and hand sanitizers. Activity evaluation is carried out 2 weeks after implementation The results showed that pregnant women experienced an increase in knowledge of more than $80 \%$ and adopt healthy lifestyle of more than $75 \%$, and felt calmer because had been accompanied and educated by the service team. The conclusion is that pregnant women have increased knowledge about Covid 19 and skills in washing hands and 
using the correct masks, so that they can prevent pregnant women from contracting Covid 19.

Keywords: Pregnant Women, Covid 19, Prevention Protocol

\section{PENDAHULUAN}

Kota Bengkulu mempunyai luas wilayah $15.594 \mathrm{~km}^{2}$ dengan jumlah penduduk sekitar 8.800 jiwa [1]. Lokasi yang merupakan pusat Kota Bengkulu ini memiliki potensi yang sangat besar karena berbagai aktifitas perkantoran, perbankan, perkuliahan, perdagangan, industri terdapat di Kota Bengkulu. [1]. Dilihat dari jumlah penduduk, lokasi dan mata pencaharian kelurahan masyarakat Kota Bengkulu mempunyai potensi tinggi terhadap penyebaran wabah penyakit Coronavirus. Wabah penyakit Coronavirus ditetapkan sebagai kedaruratan kesehatan masyarakat yang meresahkan dunia dan sudah menyebar di berbagai belahan dunia. Coronavirus adalah keluarga besar virus yang menyebabkan penyakit mulai dari gejala ringan sampai berat dan berdampak serius pada sendi-sendi ekonomi dan kesehatan masyarakat $[2 ; 3 ; 4]$.

Kota Bengkulu tertanggal 13 Oktober 2020 merupakan Kabupaten/Kota di provinsi Bengkulu yang memiliki angka positif Covid 19 terbesar yaitu 485 dengan angka kematian 30, dan pada bulan Agusus sempat menajdi tranding topic media masa karena angka kematian akibat covid salah satu daerah tertinggi di Indonesia.

Ibu hamil merupakan salah satu kelompok rentan terpapar virus covid 19, ibu hamil memiliki risiko lebih tinggi terjangkit penyakit berat, morbiditas dan mortalitas dibandingkan dengan populasi umum. Efek samping pada janin berupa persalinan preterm juga dilaporkan pada ibu hamil dengan infeksi Covid 19

Penularan covid 19 bisa disebabkan karena ketidaktahuan dan kurangnya sosialisasi apa itu covid 19, bagaimana penularannya, cara pencegahan, serta kurangya ketersediaan APD bagi masyarakat khususnya untuk ibu hamil.

Berdasarkan masalah yang dijelaskan diatas membutuhkan peran kita sebagai masyarakat untuk memutus rantai penularan Covid-19 pada ibu hamil dengan melibatkan tenaga kesehatan terutama bidan. Bidan harus mampu memberikan asuhan kebidanan yang konsisten, berdasarkan evidance based dalam memberikan dukungan pada setiap ibu dalam proses kehamilan. Salah satu upaya untuk menambah pengetahuan tentang pentingnya hidup bersih dan sehat dapat dilakukan penyuluhan dan demontrasi salah satunya bagaimana cara cuci tangan, penggunaan masker, bersin yang benar, dan pola hidup sehat serta dengan bantuan leaflet agar ibu dapat menggulang kembali jika lupa. Upaya untuk membantu melengkapi APD ibu hamil maka akan diberikan 2 lembar masker kain double layer dan 1 botol hand sanitizer ukuran 100ml, 1 botol sabun cuci tangan 100ml, dan 1 strip multivitamin (10 tablet) kepada setiap ibu hamil yang berada beberapa Kelurahan di Kota Bengkulu. [3; 5; 
$6 ; 7]$.

Berdasarkan survey awal yang dilakukan tim pengabdi yang dipilih sebagai contoh adalah 10 orang ibu hamil yang berada di Kota Bengkulu dengan satu Puskesmas dan 5 Praktek Mandiri Bidan Terdapat 6 orang ibu hamil belum mengetahui teknik atau cara yang tepat untuk mencegah penularan Covid19 pada kehamilan dan bayi yang dikandungnya, dengan demikian tim pengabdi akan memberikan pendampingan dan edukasi masa pandemi Corona Virus Disease 2019 (Covid-19) pada ibu hamil di beberapa kelurahan Kota Bengkulu METODE PELAKSANAAN KEGIATAN

Kegiatan ini menggunakan metode door to door dengan memperhatikan syarat-syarat pencegahan covid 19 dengan mengatur jarak antar minimal 1 meter saat berkunjung ke rumah ibu hamil dan menggunakan APD lengkap. Hal tersebut untuk meminimalisir penularan virus corona. Melakukan pre test untuk melihat tingkat pengetahuan dan keterampilan ibu sebelum diberikan pendampingan dan edukasi kepada khalyak sasaran menggunakan kuisioner dan daftar tilik keterampilan. Menyampaikan pengetahuan secara singkat : Apa itu Covid 19; Gejala Covid 19; Upaya pencegahan umum yang dapat dilakukan oleh ibu hamil, Apa itu hidup bersih dan pola hidup sehat serta mempraktikkan cara cuci tangan dan penggunaan masker yang benar dengan mendemonstrasikan kepada ibu hamil di rumah mereka masing-masing. Membagikan multivitamin, masker medis, sabun cuci tangan, dan hand sanitizer. Melakukan evaluasi 2 minggu setelah implementasi tentang pengetahun dan keterampilan yang disampaikan dengan mengisi kuisoner dan meminta khlayak mengulang praktik cuci tangan dan penggunaan masker yang benar.

\section{HASIL DAN PEMBAHASAN}

Tahap awal kegiatan pengabdian kepada masyarakat ini mengumpulkan literatur tentang pendidikan tentang covid 19. Selain itu dilakukan observasi awal untuk melihat kondisi lingkungan sekitar wilayah keluraha. Tahap kedua kegiatan ini adalah merancang kegiatan yaitu pendampingan dan edukasi pada ibu hamil yang dituju untuk pengabdian. Tahap ketiga yaitu menyusun metode pelaksanaan, kegiatan ini menggunakan metode sederhana yang sesuai dengan kemampuan daya tangkap masyarakat umum dengan diskusi dan tanya jawab. Tahap keempat yaitu Menyiapkan media untuk penyampaian materi, alat dan bahan untuk pelaksnaan kegiatan, pada implementasi atau pelaksanaan digunakan media leaflet sesuai kebutuhan. Tahap kelima yang telah dilaksanakan yaitu mengurus perizinan kepada pihak terkait yaitu keluahan tanah patah dan puskesmas setempat yang dituju serta telah membahas teknis penyelenggaraan pegabdian.

Tahap ke enam yaitu implementasi kegiatan yang telah dilakukan mulai 15 September-5 Oktober 2020, implementasi dilakukan dengan mengunjungi $50 \mathrm{ibu}$ hamil yang berada di wilayah sasaran yang ditetapkan. Tim dibantu dengan 2 orang 
mahasiswa yang terlibat aktif dalam proses pendampingan dan edukasi pada ibu hamil tentang pencegahan penularan Covid 19. Dapat dilihat pada Gambar 1.

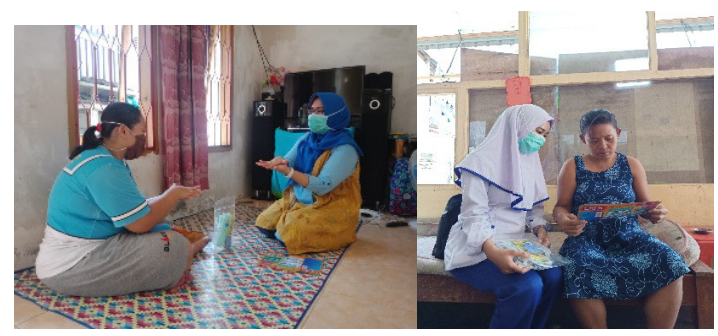

Gambar 1. Pelaksanaan kegiatan pengabdian kepada masyarakat pembinaan PNBP

FMIPA 2020

Kegiatan pengabdian kepada masyarakat yang dilakukan yaitu memberikan pendampingan dan edukasi masa pandemi corona virus disease 2019 (covid 19) pada ibu hamil di kelurahan tanah patah kecamatan ratu agung Kota Bengkulu pendampingan dan edukasi dilakukan oleh tim pengabdi secara langsung dengan bertemu dan mematuhi protokol Kesehatan pencegahan covid 19. Media yang digunakan untuk membantu pendampingan dan edukasi adalah berupa leaflet. Tujuan kegiatan penyulahan dan edukasi ini adalah untuk meningkatkan pengetahuan dan kewaspadaan ibu hamil sampai dengan $80 \%$ terhadap penularan wabah covid 19 , merubah perilaku ibu hamil untuk membiasakan hidup bersih dan pola hidup sehat minimal dari $75 \%$ peserta pendampingan dan edukasi, mencegah ibu hamil tertular Covid-19 dan dapat memberikan informasi kepada ibu hamil di kelurahan lain melalui media yang telah disiapkan.Hasil dari implementasi kegiatan ini sesuai denga tujuan yang ditetapkan yaitu lebih dari $80 \%$ ibu hamil mengalami peningkatan penegathuan dan kewaspadaan terhadap penularan Covid-19 dan lebih dari 75\%ibu hamil dapat menerapkan pola hidup bersih dan sehat. Peningkatan ini terjadi karena setiap ibu hamil telah diberi edukasi dan pendampingan pencegahan Covid-19 dan para ibu hamil telah menerapkannya dikehidupan seharihari.

\section{KESIMPULAN}

Berdasarkan kegiatan-kegiatan yang telah dilaksanakan, kesimpulan sementara yang diperoleh adalah:

1. Persiapan awal sudah semua dilakukan sesuai tahapan dan brikutnya menunggu jadwal evaluasi dan pembuatan laporan akhir serta publiksi yang telah ditentukan.

2. Implementasi kegiatan sudah dilaksanakan dengan mengunjungi ibu hamil secara langsung sesuai protokol kesehatan, menggunakan media penyampaian materi berupa leaflet dengan langsung melakukan demonstrasi cara pencegahan covid 19, dan memberikan ibu hamil suplemen untuk menjaga imunitas tubuh ibu dan pemberian masker, sabun cuci tangan serta hand sanitizer untuk dapat digunakan ibu dalam beraktifitas sehari-hari.

3. Ibu hamil sangat merasa terbantu dengan adanya pendampingan dan edukasi yang dilakukan oleh tim pengabdi.

\section{UCAPAN TERIMAKASIH}

Ucapan terima kasih kepada ibu hamil di Kelurahan Tanah Patah Kecamatan Kota 
Bengkulu yang telah membantu

terlaksananya kegiatan ini serta Fakultas

Matematika dan Ilmu Pengetahuan Alam

Universitas Bengkulu yang telah mendukung

pengabdian tersebut.

\section{REFERENSI}

[1] Badan Pusat Statistika Kota Bengkulu. 2018. Data Kependudukan Provinsi Bengkulu.

[2] WHO. 2020. Getting your workplace ready for COVID-19. URL:https://www.who.int/coronaviruse. Diakses 27 Februari 2020
[3] POGI. 2020. Rekomendasi penanganan infeksi virus corona (Covid-19) pada maternal (hamil, bersalin dan nifas). Surabaya; Pokja ISR PP POGI

[4] Dinkes Provinsi Bengkulu. 2020. Press release Covid-19. 13 Oktober 2020.

[5] Kemenkes RI. 2020. Pedoman bagi ibu hamil, ibu nifas dan bayi baru lahir selama sosial distancing. Jakarta: Dirjend Kesmas.

[6] Kemenkes RI. 2020. Media kesehatan keluarga cegah Covid-19. Jakarta; P2P

Kemenkes RI. 2020. Pedoman Pencegahan Pengendalian Coronavirus Disease (COVID-19). Jakarta: Dirjend P2P. 